\title{
REINTRODUCTION OF GOLD INTO THE FINANCIAL SYSTEM: TRENDS AND DRIVERS
}

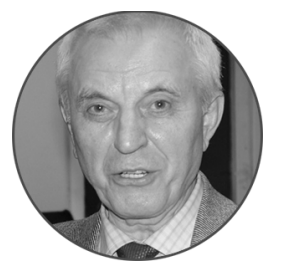

Vitalii T. BORISOVICH

Russian State Geological Prospecting University (MGPI-RSGPU), Moscow, Russian Federation

vitaly.bor37@gmail.com

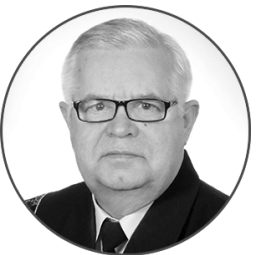

\section{Viktor M.ZAERNYUK}

Russian State Geological Prospecting University (MGPI-RSGPU), Moscow, Russian Federation zvm4651@mail.ru

\section{Corresponding author}

\section{Article history:}

Received 13 February 2018

Received in revised form

13 March 2018

Accepted 20 March 2018

Translated 10 October 2018

Available online 24 December 2018

JEL classification: E40, E44

Keywords: gold, investment, gold exchange reserve

\begin{abstract}
Subject The research is intended to examine the growing importance of gold during the economic instability in the financial markets.

Objectives The research is to study whether gold can be reintroduced into the financial system. We analyze trends and drivers in the domestic and global gold markets.

Methods The methodological underpinning comprises objective principles of a systems approach, economic analysis, logic and comprehensive approach to evaluating economic phenomena and processes.

Results Gold was found to become more popular not only from investment perspectives. Gold evidently regains the reputation of a monetary metal. Central banks sold gold from their exchange reserves until 2009. However, in 2019 they formed the demand, buying gold. The instability of the global financial system makes countries holding gold reserves abroad repatriate them.

Conclusions and Relevance Resting on the hegemony of the U.S. dollar, the global financial system perishes, paving the way to coming changes. It includes various options of the monetary circulation involving gold.
\end{abstract}

๑) Publishing house FINANCE and CREDIT, 2018

The editor-in-charge of this article was Irina M. Vechkanova

Authorized translation by Irina M. Vechkanova

\section{Introduction}

The Russian and foreign scholars conduct a growing number of researches into the current and future competitiveness of financial markets, positive and negative aspects of investing in gold, possibility of a return to a gold standard ${ }^{1}[1-5]$.

${ }^{\dagger}$ For the source article, please refer to: Борисович В.Т., Заернюк В.М. О возвращении золота в финансовую систему: тенденции и движущие силы. Финансовая аналитика: проблемы и решения. 2018. Т. 11. № 3. С. 342-353.

URL: https://doi.org/10.24891/fa.11.3.342

\footnotetext{
${ }^{1}$ Ishkhanov A.V., Linkevich E.F. [On options for returning to a gold standard]. Novaya nauka: Sovremennoe sostoyanie I puti razvitiya $=$ New Science: Current Situation and Development Paths, 2015, no. 3, pp. 110-113. (In Russ.); Kumanova L.R., Yavarova I.D. [Positive and negative aspects of investment in gold]. Ekonomika i sotsium, 2015, no. 2-2, pp. 1365-1369. (In Russ.)

URL: http://iupr.ru/domains_data/files/sborniki_jurnal/Zhurnal \%20_2(15)\%202.pdf; Sibirskaya A.V. [Status and prospects for competitiveness of the EAEU financial markets]. Finansy $i$ kredit $=$ Finance and Credit, 2017, vol. 23, no. 4, pp. 201-216.

URL: https://cyberleninka.ru/article/v/sostoyanie-i-perspektivykonkurentosposobnosti-finansovyh-rynkov-stran-eaes (In Russ.); Sukharev A.N. [The gold reserves of the Bank of Russia: Trends and current status]. Finansy $i$ kredit = Finance and Credit, 2017, vol. 23, no. 9, pp. 490-500. URL: https://cyberleninka.ru/article/v/zolotye-rezervy-
} 
Notwithstanding the official demonetization, gold continues to be a commodity and a means of payment and saving. It is noteworthy that the simultaneous performance of several functions and different insensitivity are evidence of a gold multifunctionality both in markets of commodities and financial instruments [4].

Unique qualities once made gold a means of payment and exchange. Now the same qualities shape its investment potential. What mainly positioned gold as an item for investment is the ability to protect monetary funds from impairment, and generate profit even in the time of the global market instability.

Gold becomes more lucrative for investors during global crises and economic turmoil and in financial markets, in particular. Business entities and individuals treat gold as a highly marketable financial asset. Therefore, gold is used in investment transactions as its main function nowadays ${ }^{2}$.

Investment in gold is made directly through by purchasing metals (bars or coins) or indirectly by acquiring derivatives, shares, certificates, accounts, warrants [6].

Many experts report that gold is not only perceived from perspectives of investment. Another important trend is observed as gold gradually regains its status of monetary metal [6-8]. Gold is no longer considered as ordinary commodity, turning into money, that is a common equivalent and means of exchange and payment. This signifies the turning point in the global economy and policy.

Central banks implement programs for increasing gold reserves mainly to diversify the gold exchange reserves of a respective country so as to edge out the U.S. dollar and euro and expand the use of gold.

The amount of the gold exchange reserve is indicative of the nation's financial position and considered as an important aspect for the stability of national currencies $^{3}$. An increase in the gold exchange reserve

banka-rossii-dinamika-i-sovremennoe-sostoyanie (In Russ.)

${ }^{2}$ Kumanova L.R., Yavarova I.D. [Positive and negative aspects of investment in gold]. Ekonomika i sotsium, 2015, no. 2-2, pp. 1365-1369. (In Russ.) URL: http://iupr.ru/domains_data/files/sborniki_jurnal/Zhurnal \%20_2(15)\%202.pdf.

${ }^{3}$ Predstavitel' WGC. MVF stoit rassmotret' vozmozhnost' vklyucheniya zolota I valyut razvivayushchikhsya stran v korzinu [World Gold Committee official: IMF should consider including gold and currencies of emerging economies into the portfolio of Special Drawing Rights]. URL: http://www.cbonds.info/em/eng/news/index.phtml/params/id/475088 (In Russ.) boosts up investment opportunities of any country. It mitigates the default risk associated with the external debt in case of unfavorable changes in the world and decreases the probability of drastic fluctuation of the national currency $[7,8]$.

It is globally acknowledged at the governmental level that the U.S. dollar concedes its leadership positions in the global financial system. Anticipating the coming developments, national governments elaborate different money circulation options for their countries with regard to gold. In the gold-standard-based economy, every monetary unit issued may be exchanged for gold upon request.

In 1939, the global gold reserves (except for the USSR) were 24,300 tonnes, worth 15,650 tonnes held by the USA. The USA adopted a gold standard in 1934 and exchange rate of USD 35 (the price hereinafter is given in USD per try ounce).

After World War II, the USA possessed 22,000 tonnes of gold, which also included the Soviet metal under the lend-lease policy. Having accumulated about 70 percent of national gold reserve, the USA launched the campaign for the U.S. dollar to become the world leading currency. They managed to establish the monetary system, which almost equated the U.S. dollar and gold.

The 1944 Bretton Woods Agreement envisaged a gold exchange standard pegged to gold and two reserve currencies (USD and GBP). It also affirmed gold to constitute the national reserve. Gold became the national and ultimate reserve asset.

However, as the U.S. gold reserve shrank rapidly, the system collapsed in the 1970s. In 1971, the USA devalued the U.S. dollar and declared the U.S. dollar would not longer be exchanged for gold, trying to squeeze gold out of the international monetary circulation. In 1976, members of the International Monetary Fund (IMF) articulated principles of a new currency system, which are still effective.

The U.S. dollar was accepted as a financial equivalent worldwide. The gold exchange standard was abolished concurrently with the approval of the gold demonetization, thus signifying that gold was no longer considered as money.

After the U.S. dollar was unpegged from gold, USD issue became almost unlimited. The world supply of the U.S. dollar is 25 times as much as the value of goods 
produced. Over 80 percent of the USD supply float outside the USA. Whereas the currency is no longer pegged to gold, financial authorities can make relatively arbitrary money issues. Sometimes this generates an excess of money circulating in the economy, triggers a growth in prices and fuels inflation. Gold appreciated from USD 35 to USD 1,900 from 1967 to 2017, i.e. a 50fold increase.

The U.S. dollars turned into liabilities of the U.S. Federal Reserve System. It is the Federal Reserve System that is empowered to control the volume of money issue.

The Federal Reserve System is exclusively mandated to produce the currency. Thus, the U.S. dollars gradually and inconspicuously morphed into the so called unsecured representative currency, i.e. a promissory note of the Federal Reserve System. According to analysts' estimates, the U.S. dollar lost 98 percent of its value last year ${ }^{4}$.

Therefore, each entity holding a USD banknote virtually acts as a creditor of the Federal Reserve System. As a result of the financial policy of the Federal Reserve System, the national debt increased 5,000 times.

Is the bankruptcy scenario applicable to the Federal Reserve System? Yes, it is, like it may happen with any business entity. In the case of the Federal Reserve System and the U.S. dollar as the global reserve, the bankruptcy may have shattering effects on global powers as a whole, rather than one single country.

If the Federal Reserve System goes bankrupt, the value of the Federal Reserve Notes, which are often erroneously understood as the U.S. dollars, may slump down to their real value worth 7 to 10 percent per USD, thereby impairing the financial position of entities holding them.

Many countries voice their concerns about the currency system as is currently observed. Here is a question to be answered. Is the strongest economy trustworthy? Its national debt currently amounts to USD 20.16 trillion, exceeding GDP of USD 19.3 trillion by 100 percent ${ }^{5}$.

The Chairman of the Federal Reserve Alan Greenspan announced the USA intends to reintroduce a gold standard, referring to recommendations of the U.S.

\footnotetext{
${ }^{4}$ Lezhava A. Ob odnom yubilee [On an anniversary]. URL: http://trueinform.ru/modules.php?name=News\&sid=22889 (In Russ.)

${ }^{5}$ Gosdolg SShA prevysil 20 trln doll [The U.S. national debt exceeds USD 20 trillion]. URL: https://topwar.ru/124735-gosdolg-ssha-prevysil20-trln-doll.html (In Russ.)
}

Gold Commission set up in 1981 and considering the probable USD devaluation of 40 percent [10].

As the analysis shows, gold constantly regains its status of a monetary metal ${ }^{6}$. As noted by S.M. Borisov in 2005, the world sees gold crawling back into the monetary system [10].

\section{Purchase of Gold for Reserves}

Central banks have been selling gold from their gold exchange reserves for the recent two decades. Over 5,000 tonnes of metal have been disposed of for this period of time. However, in 2010, central banks started to create the demand and buy gold. They revised their attitude to gold reserves, which currently serve for stabilizing the exchange rates of national currencies.

Central banks have been busy incrementing their gold reserves for seven years. The trend is expected to survive in 2018 as well, especially in the Asian countries. According to official data, the People's Bank of China holds less than two percent of gold (Table 1).

As many experts note, the People's Bank of China continues to diversify its substantial gold exchange reserves and convert them into gold to protect them from the weakening U.S. dollar. To confer the status of global reserve currency on the yuan, China shall ensure that gold accounts for 10-15 percent of the gold exchange reserves.

According to estimates ${ }^{7}$, the People's Bank of China should buy another 1,900 tonnes of gold so that it would account for 5 percent of its holdings, i.e. being equal to the volume of gold produced for a nine month time worldwide or the gold production output in China for a 66 month time.

In the mean time, even if gold accounts for five percent of the national gold exchange reserve, it is still too little. As analysts believe, the People's Bank of China will continue buying gold in the nearest future, through remaining dependent on its import, notwithstanding an increase in gold production. This is because the Asian countries will also accumulate their gold reserves, trying to catch up with the European countries holding about 60 percent, and replenishing their gold

\footnotetext{
${ }^{6}$ Katasonov V. Zoloto: vozvrashchenie $v$ mir deneg [Gold: A return to the world of money]. URL: http://www.faito.ru/news/1364816557 (In Russ.)

${ }^{7}$ Dragotsennye metally: Aziya podtolknet kotirovki zolota werkh [Precious metals: Asia will create an upward trend in gold]. URL: https://www.rbc.ru/economics/17/10/2011/5703ed829a79477633d38eb 7 (In Russ.)
} 
exchange reserves by 10-15 percent within the coming 10 to 12 years. Consequently, the market will need about 18-20 tonnes of new gold so as to maintain the demand and price for gold. Thus, central banks of the Asian countries will assume control over the gold market.

Being another large emerging economy, Brazil intends to increase the gold production output up to 180 tonnes within 2014-2022, which is trice as high as the current production output.

The peculiar situation in the gold market is observed in India, which produces about three tonnes of gold annually. However, India remains one of the major gold importers holding the most affluent deposits of processed gold, which are estimated to contain about 10 thousand tonnes. India's gold bullion stock is assessed to account for 50 percent of the national $\mathrm{GDP}^{8}$. Moreover, India's Ministry of Mines set out to extract up to 45 tonnes of gold per year.

Russia is among top gold buying countries, thus being on the Top 5 list of the largest gold holders. It possesses 1,680 tonnes in gold reserves, i.e. 16 percent of the global reserves.

The Central Bank of Russia purchased 201 tonnes of the precious metal in gold reserves in 2017. In fact, this has been the record high purchase since the collapse of the USSR. The Central Bank of Russia buys gold from the Russian gold extracting companies so as to become less dependent on the U.S. dollar and diversify its reserves.

Many countries acquire more gold. India increased its gold reserves by 56 percent, up to 557 tonnes. Brazil, Iraq, Turkey, Kazakhstan, Azerbaijan, Belarus and some other countries are the main trend setters. Table 1 presents the key global holders of gold reserves [11].

\section{Supply and Demand in the Global Gold Market}

The gold market has faced challenging trends for the recent months. Diverse factors made it difficult to understand the future market scenarios. Investors are guessing whether gold prices will be bullish or bearish.

Unstable sentiment about the U.S. monetary policy and its impact on the USD exchange rate turned to be

\footnotetext{
${ }^{8}$ Gornodobyvayushchaya promyshlennost' I zolotodobycha v Indii [Gold extraction industry and gold production in India]. URL: https://zolotodb.ru/articles/foreign/10657 (In Russ.)
}

the most influential factor. We agree with analysts stating that the overall macroeconomic environment remains favorable for gold ${ }^{9}$. We draw this conclusion with reference to the meeting of the Federal Open Market Committee (FOMC) ${ }^{10}$ in March 2017 where participants doubted that the U.S. monetary policy would hardly be restricted more rapidly.

In our opinion, some macroeconomic and geopolitical risks may make gold even more lucrative for investors. Considering that speculative positions are relatively low at the beginning of 2018, there is a strong likelihood of an increasing flow of investment in gold within the coming months.

In 2016, on-ground stocks of gold amounted to 186,200 tonnes (Fig. 1). Table 2 shows the global supply and demand for a seven-year period. The extraction volume of 3,255 tonnes is the seventh annual record, being trice as high as was ten years ago. We believe that the overall macroeconomic environment is benevolent for gold.

As observed in the market of physical metal, the respective demand in the segment is unlikely to spur a growth in gold prices. Obviously, there will not be a slight decrease in the extraction volume as expected.

The gold extraction volume is likely to remain the same in 2018 and in the mid-term. Prices for gold denominated in foreign currencies are still high. Even if translated into USD, they are much higher than the historical average. Thus, in the foreseeable future, gold production will be profitable for most gold producing enterprises.

As for positive factors, some key markets will see that absolutely favorable conditions of the previous year will gradually subside, with the supply of scrap gold dropping.

The supply exceeding the demand in the market of gold in 2016 matched the amount of purchases made by the Western institutional investors. 532 tonnes in the net flow of the metal added to the exchange-traded mutual funds, which invest in physical gold, and a growth of 329 tonnes in investors' futures on the Comex marketplace almost equal an excess of 862 tonnes. The data correspond with the trading statistics

\footnotetext{
${ }^{9}$ American Appraisal. Zoloto 2017 [American Appraisal Research. Gold Focus 2017].

URL: http://gold2017.american-appraisal.ru/img/gold_2017_preview.pdf (In Russ.)

${ }^{10}$ Federal Open Market Committee within the U.S. Federal Reserve System.
} 
and information about a considerable flow of gold bullion during the previous year in the United Kingdom, where many institutional investors hold gold.

We should emphasize that investment in gold bars and gold coins dropped by 9 percent, amounting to 1,057 tonnes (gold bars by 10 percent, i.e. down to 787 tonnes, and coins by 5 percent, i.e. down to 271 tonnes). In 2017, the demand increased by 25 percent in China, reaching the second record high value in history. Investors seek dealing with gold since the market sentiment improved concurrently with a growing uncertainty of macroeconomic indicators [10].

In 2016, the extraction pace slowed down, reaching 1.1 percent due to a lower impact of new projects. The gold extraction volume of 3,255 tonnes, which was registered the previous year, is approximately one-third as high as was a decade ago.

Gold producing companies make hedging transactions, thus generating the additional supply of 33 tonnes for three consecutive years.

In 2016, the scrap gold reprocessing volume rose by 16 percent, up to 1,296 tonnes worldwide. It has been the first time increase for the previous four years. China reproduces the largest amounts of scrap gold (a 37 percent growth).

Investment in physical gold fell by 2 percent, down to its record low for the decade. This is due to the fact that emerging economies invest less in gold since growing prices for gold denominated in national currencies not only limited their purchasing ability, but sometimes engendered the selling trend in pursuit of profit.

In 2017, the most considerable reduction in investment was observed in Iraq and India, where the demand also fell due to governmental measures against the shadow economy. China again breaks this pattern, seeing the demand increase by 25 percent the previous year up to the second record high value for its entire history.

Investors demonstrate more interest in gold due to better market sentiment and growing uncertainty of macroeconomic indicators. In particular, the renminbi depreciated substantially, while limited capabilities of investing in alternative assets made investors focus on gold.

Governmental institutions buy gold less than ever for the previous six years. However, Russia and China have acquired much gold for the recent years.
China buys less gold as more pressure is put on the People's Bank of China so that it could undertake the renminbi stabilization measures.

Russia demonstrates stability in gold purchases since it can buy it in the local market without using foreign currency reserves.

The public sectors of other countries remained the net buyers of gold to diversify the gold exchange reserve portfolio. However, those purchases were not substantial.

Having analyzed the demand and supply in the market of gold, we opine that some macroeconomic and geopolitical risks can even lure investors into dealing with gold. Considering that speculative positions were insignificant at the beginning of 2017, investors are very likely to put up their funds in gold.

It is noteworthy, there was about 800 tones and 3,255 tonnes in 1950 and 2016 respectively, thus demonstrating a 400-percent increase ${ }^{11}$. Whereas 3,255 tonnes of gold were extracted in 2017, deposits rose by 2 percent only, being rather mediocre from historical perspectives. This slight increase gives us a hint why many investors believe in the long-standing value of gold, especially in comparison with monetary funds the supply of which usually grows faster.

For example, if the stocks of extracted gold have almost doubled since the late 1960s, the supply of the U.S. dollars in circulation (aggregate M1) demonstrated a 17fold upturn. It is worth mentioning that the volume of extracted gold increased correspondingly with the world population, which has also doubled. However, it was substantially lower than a seven-fold growth in the global GDP in real terms.

Therefore, while influencing national economies, the market of gold gives grounds to be treated as a target of governmental regulation [12]. That being said, we assume gold is likely to become a means of governmental control in the nearest future, thereby modifying functions of this precious metal. Countries with the largest gold deposits will have the most powerful say in tackling crucial issues ${ }^{12}$.

\footnotetext{
${ }^{11}$ Barsegyan A.G. [Prospects for reforming the global currency system]. Uchenye zapiski Tavricheskogo natsional'nogo universiteta imeni V.I. Vernadskogo = Scientific Notes of the V.I. Vernasky Crimean Federal University, 2011, vol. 24, no. 1, p. 26. (In Russ.)

${ }^{12}$ Borisovich V.T., Madzhidov B.S., Garaev E. [Analysis of gold production leades in today's market]. Razvedka $i$ okhrana nedr $=$ Prospect and Protection of Mineral Resources, 2016, no. 4, pp. 59-63. (In Russ.)
} 
Demand for gold will generally have a positive effect on the gold extraction industry, motivate entities dealing with gold extraction and geological survey and contribute to the supply of gold in the global market.

\section{Repatriation of Gold Reserves}

If national gold reserves are stored abroad, countries try to repatriate them. Germany returned a portion of its gold reserves. According to other data, Germany was denied to check the physical availability of its gold bars.

It seems unacceptable to store 70 percent of the national gold reserves abroad. Germany intends to repatriate a half of its national gold reserves by 2020 .

This intention was shared by some other European countries (The Netherlands, Austria, Italy, France, Belgium), whose gold reserves have been stored elsewhere since the 1930s. The European countries totally had 10,786 tonnes in December 2016, thus making euro the most gold-backed currency.

Gold repatriation ideas are mushrooming, turning into a stable and common trend. Such countries as Ecuador, Venezuela, Iran, Libya, Azerbaijan and others have already announced similar intentions.

Why do many countries claim their gold reserves back? Lack of trust is the only reason. According to official data, the USA holds the largest stock of gold reserves, amounting to 8,134 tonnes in early 2017 . In the mean time, there are doubts concerning the real existence of this stock because gold reserves have not been revised since 1950.

Mass media reports on some outrageous incidents, mentioning a shipment of 5,700 gold bars originated from the USA in 2009 to China (11 kg each). Upon the decision of the Chinese government, the delivered gold was analyzed and tested. The gold bars were discovered to be bogus, being simply coated with gold.

In March 2011, the bogus gold from the USA was located in Vietnam. In the following case, the USA suspended a shipment of 191 tonnes of gold to the International Monetary Fund. The IMF Managing Director D. Strauss-Kahn received a confirmation of the U.S. gold reserves depletion ${ }^{13}$.

\footnotetext{
${ }^{13}$ Voznesenskii S. SShA ostalis' bez zolotogo zapasa [The USA left without gold reserves].

URL: http://topwar.ru/5918-ssha-ostalis-bez-zolotogo-zapasa.html (In Russ.)
}

In addition to gold reserves, the USA also stores some or full gold reserves of other thirty countries. The countries totally deposited 6,029 tonnes of gold there. There are no mass media publications on the amount of gold reserves. Custodians avoid the gold being audited, thereby fueling various rumors and speculations. Will the USA be able to return the gold it accepted to store in its gold vault holdings?

As the analysis shows, the USA and some European countries tend to suppress prices for gold as their main policy in this aspect. They are persistent in their efforts to undermine the importance of gold as an international reserve currency. They try to prevent other countries from using their gold reserves instead of the U.S. dollars and euro. Therefore, it is very beneficial for the USA to suppress the price for gold in order to reinforce the U.S. dollar as an international reserve currency.

After the gold standard was abolished in 1971, countries continued to form their gold reserves, indeed. Some central banks of major countries, including Russia, have been actively and persistently replenishing its gold vaults since the 1990s. As experts say, doing so, national governments secure their respective countries against a global financial catastrophe. Experts believe that realistically minded countries elaborate their own projects for backing their currencies with gold. Although there is little likelihood that the above will happen, such projects boost a growth in prices for gold, precluding their drop in the foreseeable future ${ }^{14}$.

The national gold reserve is of international significance as an international asset because it is indicative of the monetary and financial position and creditworthiness of a country.

As other countries create and increment their gold holdings, the USA excoriates the practice, trying to preserve the U.S. status of a reserve currency ${ }^{15}$.

\footnotetext{
${ }^{14}$ Kuznetsov A.V. [China's currency policy: A challenge to U.S. Hegemony?]. Finansy $i$ kredit = Finance and Credit, 2017, vol. 23, no. 16, pp. 914-926. URL: https://cyberleninka.ru/article/v/valyutnaya-politikakitaya-vyzov-gegemonii-ssha (In Russ.);

Ekimov A.V., Gorbunova N.V., Novokreshchenova O.A. [Strategic partnership as a factor of enhancing the competitiveness of financial market actors]. Finansy $i$ kredit = Finance and Credit, 2016, no. 35, pp. 15-26. URL: https://cyberleninka.ru/article/v/strategicheskoepartnerstvo-kak-faktor-povysheniya-konkurentosposobnosti-subektovfinansovogo-rynka (In Russ.)

${ }^{15}$ Shchedrova O. Rost nakopleniya zolota i mirovaya finansovaya sistema [A growth in accumulation of gold and global financial system]. URL: http://rf-smi.ru/analitika/17846-rost-nakopleniya-zolota-imirovaya-finansovaya-sistema.html (In Russ.)
}

368 Digest Finance, 2018, vol. 23, iss. 4, pp. 363-372. https://doi.org/10.24891/df.23.4.363 


\section{Preference of Regional (Local) Currency}

Facing another global economic crisis, some countries (China, Russia, Iran, South Africa, Norway, Switzerland, South Korea, Taiwan, many countries of Latin America and Islamic countries) initiated talks on the use of gold for international settlements and payments ${ }^{16}$.

China proceeds to conclude bilateral agreements (with Japan, Russia, other BRICS nations) on the reciprocal use of national currencies. Experts reasonably suggest that the exchange rate of national currencies should be assessed by the gold parity of the currency, rather than the stock exchange as it is done today.

If a country prefers its local (regional) currency, it recurringly expresses the growing discontent with the U.S. policy. Economic sanctions make Turkey pay for Iran's hydrocarbons with gold because the USA prohibited the ordinary payment procedure. Likewise China has to search for roundabouts when paying to Iran for the supply of hydrocarbons. The People's Republic of China may possibly use gold for this transactions too ${ }^{17}$.

Certain States resort to the precious metal for international payments, so to say, without preliminary permission. So, gold serves as a means of payment in dubious schemes and even smuggling. For example, about two-thirds of goods imported to Nepal from India are paid for with gold.

However, there are other reasons why some countries were subject to stringent sanctions. Tackling economic sanctions of the Western countries, Iran prohibited payments for import and export transactions, thereby forcing Turkey to pay for natural gas imported from Iran with gold.

\footnotetext{
${ }^{16}$ Kuznetsov A.V. [China's currency policy: A challenge to U.S. hegemony?]. Finansy $i$ kredit = Finance and Credit, 2017, vol. 23, no. 16, pp. 914-926. URL: https://cyberleninka.ru/article/v/valyutnaya-politikakitaya-vyzov-gegemonii-ssha (In Russ.);

Ekimov A.V., Gorbunova N.V., Novokreshchenova O.A. [Strategic partnership as a factor of enhancing the competitiveness of financial market actors]. Finansy $i$ kredit $=$ Finance and Credit, 2016, no. 35, pp. 15-26. URL: https://cyberleninka.ru/article/v/strategicheskoepartnerstvo-kak-faktor-povysheniya-konkurentosposobnosti-subektovfinansovogo-rynka (In Russ.).

${ }^{17}$ Ofitsial'naya statistika zolotogo importa Kitaya - verkhnyaya chast' aisberga: zachem Podnebesnoi stol'ko dragotsennogo metalla? [Official statistics of the Chinese import of gold is the iceberg peak. Why does China need so much precious metal?].

URL: http://www.oilru.com/news/363892 (In Russ.)
}

Certain Islamic countries, China and Switzerland have been voicing ideas of gold-backed dinar, yuan and franc for several years. Top public officials discuss the return of gold to the domestic monetary circulation in Sweden, Norway, South Africa, South Korea, Iran, Taiwan, and some countries of Latin America.

The U.S. dollar has been unstable and volatile for the recent several years. Hence, there are multiple suggestions in diamond production, oil and gas industries to substitute it with the other currency or asset representing a currency basket.

Anticipating the collapse of the U.S. dollar, global market actors paid their attention to gold. Gold proved to be an unparalleled in financial dealings.

According to the resolution of the Basel Committee on Banking Supervision (Basel III Accord), gold is a real financial asset, which is considered as the most reliable treasuries, cash for equity assessments. Furthermore, some countries adopted the provisions of Basel III Accord, while the U.S. banks and most European countries failed to comply with it.

The 2008 financial crisis ignited new arguments and debates about the reintroduction of a gold standard, which implies that fiat money should be backed with gold held by a State. Under such circumstances, the exporting country gains an additional advantage since it is able to accumulate a lot of gold. This empowers the country to issue more money in circulation and subsequently fund its own economy. In the mean time, major gold producers become macroeconomically influential as they sell the precious metal in the market.

\section{Gold-Based Monetary Systems}

The e-gold system was launched in 1996 and supposed to process international transfers. The e-gold system protected parties to international transactions from the foreign exchange risk.

It is interesting to analyze not only the gold and monetary profile of various countries, but also internal circumstances and events. For example, the USA. As reported in the mass media (September 2011), the U.S. President D. Trump required lessee to pay their rent with gold, rather than the U.S. dollars.

Many U.S. states, indeed, vote for gold-backed money. For example, the Utah government adopted and enacted the law on hard money. This law encourages to 
use silver and gold coins produced by the U.S. Mint and accepts them as payment for goods and services, with their value corresponding with the weight of the precious metal in them.

In 2014, Arizona passed the bill making precious metals legal tender. Legislature in other U.S. states (Idaho, Washington, Virginia, Georgia, Indiana, Colorado, Minnesota, Missouri, Montana, New Hampshire, Tennessee and South California) consider bills recognizing gold and silver coins legal tender too. It is noteworthy that most of the above U.S. states suggest using not only coins produced in the U.S. Mint, but also those of other countries.

Resonating with the sentiment and needs of businesses and people, some private companies offered the so called gold-backed products.

As the analysis shows, gold has been an equivalent of money for thousands of years (unit of account), being used as a medium of payment, saving and global money later on. However, nowadays credit money pushed gold out of local and international circulation. The precious metal is no longer exchanged for goods directly. Prices for gold are not set. It caused monetary functions of gold to modify. Gold is not used as a means of payment, however, it is still perceived as international money in case of emergency to secure international loans, and a symbol of wealth.

We agree with those economists and experts who advocate for gold-backed currency to alleviate crisis implications. The fact that many countries increment their protective gold holdings is economically meaningful and important.

It is reasonable for any country to store its gold reserves internally since gold can be a hedge against risks that the existing financial system will collapse. Hence, gold can regain its monetary functions.

\section{Table 1}

The major holders of gold reserves

\begin{tabular}{llll}
\hline Country & Gold reserves, tonne & Percentage of total gold exchange \\
\cline { 2 - 4 } & $\mathbf{2 0 0 7}$ & $\mathbf{2 0 1 7}$ & $\mathbf{7 4}$ \\
\hline USA & 8,134 & 8,134 & 68 \\
\hline Germany & 3,417 & 3,378 & 67 \\
\hline Italy & 2,452 & 2,452 & 62 \\
\hline France & 2,622 & 2,436 & 2 \\
\hline China & 600 & 1,843 & 16 \\
\hline Russia & 438 & 1,816 & 6 \\
\hline Switzerland & 1,166 & 1,040 & 2 \\
\hline Japan & 765 & 765 & 63 \\
\hline Netherlands & 624 & 612 & 5 \\
\hline India & 358 & 558 & \\
\hline
\end{tabular}

Source:Authoring based on the IMF data 


\section{Table 2}

Supply and demand in the international gold market in 2010-2016, tonne

\begin{tabular}{llllllll}
\hline Metric & $\mathbf{2 0 1 0}$ & $\mathbf{2 0 1 1}$ & $\mathbf{2 0 1 2}$ & $\mathbf{2 0 1 3}$ & $\mathbf{2 0 1 4}$ & $\mathbf{2 0 1 5}$ & $\mathbf{2 0 1 6}$ \\
\hline Supply & & & & & & & \\
\hline Extraction & 2,766 & 2,852 & 2,933 & 3,077 & 3,148 & 3,220 & 3,255 \\
\hline Scrap gold reprocessing & 1,526 & 1,675 & 1,711 & 1,263 & 1,189 & 1,120 & 1,296 \\
\hline Supply o gold as a hedge & - & 32 & - & - & 105 & 13 & 33 \\
\hline Total supply & 4,292 & 4,559 & 4,645 & 4,340 & 4,442 & 4,353 & 4,584 \\
\hline Demand & & & & & & & \\
\hline Consumption of gold in jewelry industry & 2,112 & 2,180 & 2,198 & 2,748 & 2517 & 2,448 & 1,949 \\
\hline Industrial consumption & 441 & 385 & 363 & 350 & 349 & 332 & 323 \\
\hline Net investment in physical gold & 1,130 & 1,389 & 1,287 & 1,702 & 1038 & 1,048 & 1,032 \\
\hline Net hedging by producers & 118 & - & 47 & 25 & - & - & - \\
\hline Net purchase by central banks & 104 & 516 & 582 & 646 & 584 & 577 & 377 \\
\hline Total demand & 3,876 & 4,471 & 4,478 & 5,471 & 4,487 & 4,404 & 3,722 \\
\hline
\end{tabular}

Source: Authoring based on the Metals Focus data

\section{Figure 1}

Above-ground stocks of gold in 2016, tonne

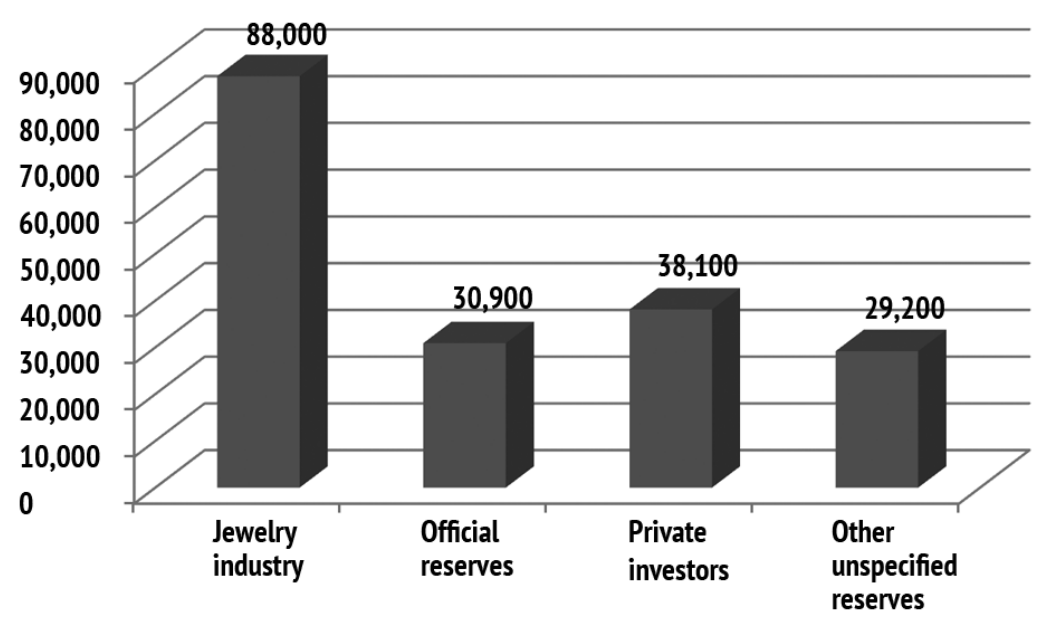

Source:Authoring based on the World Gold Council data

\section{References}

1. Loginov E.L., Lukin V.K., Loginova V.E. [Combined gold and foreign currency transactions in global financial markets: a new USD strategy of the United States]. Finansovaya analitika: problemy i resheniya = Financial Analytics: Science and Experience, 2015, no. 17, pp. 2-10.

URL: https://cyberleninka.ru/article/n/kombinirovannye-zolotovalyutnye-operatsii-na-mirovyh-finansovyhrynkah-novaya-dollarovaya-strategiya-ssha (In Russ.)

2. Parshina L.N. [The role of gold in reserves of countries]. Finansy $i$ kredit = Finance and Credit, 2016, no. 23, pp. 2-8. URL: https://cyberleninka.ru/article/n/rol-zolota-v-rezervah-stran (In Russ.)

3. Borisovich V.T., Gaganov S.Yu. [Investment entity of gold as a basis for efficiency gold mining]. Izvestiya vysshikh uchebnykh zavedenii. Geologiya i razvedka = Proceedings of Higher Schools. Geology and Exploration, 2015, no. 3, pp. 73-79. (In Russ.)

Please cite this article as: Borisovich V.T., Zaernyuk V.M. Reintroduction of Gold into the Financial System: Trends and Drivers. 
4. Kuznetsov V.S. [Would a gold standard help the Russian ruble to become a reserve currency]. Vestnik MGIMOUniversiteta, 2011, no. 1, pp. 207-211.

URL: http://www.vestnik.mgimo.ru/sites/default/files/vestnik/2011-16-1.pdf (In Russ.)

5. Kombarov M.S. Vozvrat mirovoi valyutnoi sistemy k klassicheskomu zolotomu standartu $v$ roli edinoi mirovoi valyuty [The return of the global monetary system to the classic gold standard as a single world currency]. Almaty, 2012, 30 p. URL: http://group-global.org/sites/default/files/publications/\%20G-20\%20-\%20дорожная\%20карта \%20по\%20созданию\%20глобальной\%20валюты.pdf (In Russ.)

6. Borisov S.M. Mirovoi rynok zolota na sovremennom etape [World market of Gold]. Moscow, IMEMO RAS Publ., 2005, $221 \mathrm{p}$.

7. Gaganov S.Yu. [Research of demand for gold as a tool of influence on the national economics]. Rossiiskoe predprinimatel'stvo = Journal of Russian Entrepreneurship, 2014, vol. 15, iss. 7, pp. 10-25.

URL: https://creativeconomy.ru/lib/8490 (In Russ.)

8. Grinspen A. The Age of Turbulence: Adventures in a New World. London, The Penguin Press, 2015, 520 p.

9. Hankel W., Isaak R. The Brave New World Economy: Global Finance Threatens Our Future. Hoboken, New Jersey, John Wiley \& Sons, 2011, $270 \mathrm{p}$.

10. Levin J.E., Wright E.R. Short-run and Long-run Determinants of the Price of Gold. Research Study No. 32. London, World Gold Council, 2006, 64 p.

URL: http://pure.strath.ac.uk/portal/files/64981641/strathprints007215.pdf

11. Mitchell D.B. Dismantling the Cross of Gold: Economic Crises and U.S. Monetary Policy. North American Journal of Economics \& Finance, 2000, vol. 11, iss. 1, pp. 77-104.

12. Smith M.L. A Monetary Explanation of Distribution in a Gold Money Economy. University of Sydney, School of Economics Working Papers - Economics, 1995, no. 223. URL: http://hdl.handle.net/2123/7471

\section{Conflict-of-interest notification}

We, the authors of this article, bindingly and explicitly declare of the partial and total lack of actual or potential conflict of interest with any other third party whatsoever, which may arise as a result of the publication of this article. This statement relates to the study, data collection and interpretation, writing and preparation of the article, and the decision to submit the manuscript for publication. 